\title{
POTRET DIRI WANITA MUSLIMAH (Studi Fenomenologi Wanita Pekerja Karet di Kuala Mandor B Kabupaten Kuburaya)
}

\author{
Muhammad Munir \\ STAI Al-Azhar Menganti Gresik \\ muniralafasy39@gmail.com \\ Dwi Putri Robiatul Adawiyah \\ UIN Sunan Ampel Surabaya \\ putrirad@gmail.com
}

\begin{abstract}
extreme work was done by Muslim women, their courage in doing slicing the bark of rubber tree to get the latex (noreh) alone in the middle of the night located in the forest.This work really made the researchers amazed.It was interesting to be adopted by all women moslem that they can learnin and understand the life of a Muslim woman that happened in the village clearly. The method of the study uses descriptive qualitative research and the approach is Phenomenology Study, using data collection methods: interviews, observation and documentation, which include Muslim women, rubber workers, and including the people in the village. The location of this study is in the district of Kaula Mandor B, Kuburaya Regency by snowball regardingMuslim women plays an important role in family such as parenting children, obeying their husbands and their parents. While in data analysis, researchers would analyze, explore data. Data analysis is directed at research questions, data reduction, and synthesis. Triangulation and extension of participation is used as checking the validity of the data. The results of this study are the role of Muslim women, the courage of Muslim women, the upbringing of Muslim women, and self-portraits of Muslim women in Islam.
\end{abstract}

\section{Keywords: Self-portrait, Muslim Women, Rubber Workers}

\begin{abstract}
Abstrak
Pekerjaan yang ekstrim yang dilakukan oleh wanita muslimah, keberanian mereka dalam melakukan pekerjaan melukai pohon karet untuk mendapatkan getahnya (noreh) sendirian di tengah malam yang berlokasi di hutan, pekerjaan ini sangat membuat peneliti kagum sehingga menarik untuk di angkat dalam sebuah penelitian ini agar semua wanita muslimah memahami begitu berat kehidupan seorang muslimah yang terjadi di desa tersebut. Metode penelitian ini menggunakan jenis penelitian kualitatif
\end{abstract}


deskriptif dan pendekatannya Studi Fenomenologi, dengan menggunakan metode pengumpulan data: wawancara, observasi dan dokumentasi, yang meliputi wanita muslimah, wanita pekerja karet, serta termasuk masyarakat yang ada di desa tersebut. Adapun lokasi penelitian ini bertempat di kecamatan Kaula Mandor B Kabupaten Kuburaya dengan cara snowball. Dengan pertimbangan wanita muslimah berperan penting dalam berkeluarga seperti pola asuh anak, taat kepada suami dan kepada orang tuanya. Sedangkan dalam analisis data peneliti akan menganalisis, mengeksplorasi data. analisis data diarahkan pada pertanyaan penelitian, reduksi data, sintesisasi. Triangulasi dan perpanjangan keikutsertaan sebagai pengecekan keabsahan data. Hasil dari penelitian ini ialah Peran Wanita Muslimah, Keberanian Wanita Muslimah, Pola Asuh Anak Wanita Muslimah, Potret diri wanita muslimah dalam Islam

\section{Kata Kunci : Potret Diri, Wanita Muslimah, Pekerja Karet}

\section{Pendahuluan}

Wanita muslimah identik dengan sebuah pakaian syar'i bahkan tidak jarang yang menggunakan cadar, tingkah laku baik dan sopan, pribadi yang muslimah, selalu menundukan pandangan dan selalu berada dirumah, serta tidak keluar rumah kecuali di temani oleh seorang suami atau keluarga muhrim.

Dalam sudut pandang islam wanita muslimah berarti mereka yang memeluk agama Islam, serta taat menjalankan segala bentuk perintah Allah yang tertulis di dalam Al-Qur'an dan Hadist. Termasuk mereka yang harus beriman kepada Allah SWT. Muslimah yang sejati adalah mereka yang selalu taat kepada Allah dan Rasul-Nya, disisi lain mereka harus bisa mengimplementasikan nilai-nilai amar ma'ruf nahi mungkar. ${ }^{1}$

1 A Sri Suriati Amal, Role Juggling: Perempuan Sebagai Muslimab, Ibu, Dan Istri. (Jakarta: PT. Gramedia Pustaka., 2006), 1. 


\section{Muhammad Munir, Dwi Putri Robiatul Adawiyah}

Muslimah yang hakiki ialah muslimah yang selalu menjalankan perintah yang wajib seperti sholat lima waktu, puasa ramadhan dan ibadah-ibadah wajib yang lainnya. Serta tidak lupa dengan segala bentuk pekerjaan yang disunnahkan sebagaimana yang dianjurkan oleh rasulullah. Disamping itu seorang wanita muslimah bisa menjaga aurat karena wanita adalah makhluk Allah yang dimuliakan, tujuan lain dari menutup aurat adalah menjauhkan segala bentuk fitnah selain muhrim dari wanita tersebut. Kelalaian dalam menutup aurat ini membuat orang yang memandanganya bisa menghantarkan pada perbuatan zina. $^{2}$

Seorang muslimah memiliki budi pekerti baik yang melekat dalam dirinya. Budi pekerti tersebut berimplementasi dari tutur katanya yang lemah lembut, sopan dan santun. Selain memiliki

2 Ibid, 4. karakter tersebut seorang wanita muslimah harus memiliki kesabaran yang tinggi. Jika dilihat konsep sabar dari sudut pandang psikologi, antara lain rasa syukur (gratitude) dan pemaaf (forgiveness). Konsep pemaafan (forgiveness) ini telah banyak berkembang termasuk di Indonesia sendiri forgiveness sudah banyak yang mengembangkan. ${ }^{3}$

Wanita muslimah juga memiliki kewajiban untuk berbakti kepada suami dan orang tuanya. Bentuk dari berbakti kepada suami dan kepada orang tua ialah yang berusaha memberikan sebuah keringanan dengan memberikan sebuah bantuan kepada mereka. Hal inilah implementasi seorang wanita muslimah yang baik bukan malah sebaliknya, karena ketika seorang wanita tidak berbakti dia akan di benci oleh Allah SWT. ${ }^{4}$

\footnotetext{
${ }^{3}$ Sri Suriati Amal, 4.

${ }^{4}$ A Salem Bahammam, Keluarga Dan Akblak Dalam Islam. (Modern Guide., 2007), 3 .
} 
Vol. 13, No. 2, Oktober 2020

p-ISSN:2086 -0749

e-ISSN:2654-4784

Wanita muslimah harus memiliki ilmu yang bisa mengurus keluarganya. Karena seorang ibu adalah guru pertama bagi seorang anak yang bisa memberikan petunjuk dalam kehidupannya. Karena pola asuh seorang ibu bisa memberikan pengetahuan kepada seorang anak yang bisa membahagiakan orang tuanya kelak, ketika pola asuhnya baik maka yang tertanam dalam diri seorang anak sikap siddiq, amanah, tabligh, fatonah seperti yang sifat yang dimiliki oleh rasulullah. $^{5}$

Islam sendiri memandang bahwa wanita memiliki posisi yang setara dengan laki-laki, dalam hal ini kesetaraan yang dimaksud yaitu hak untuk mendapat pendidikan yang sama, hak untuk berada di posisi lembaga yang sama, serta

${ }^{5}$ A Syarbini, Model Pendidikan Karakter Dalam Keluarga. (Jakarta: PT Elex Media Komputindo., 2014), 7. mendapatkan pekerjaan yang layak. Gerakan Feminisme merupakan sebuah kepercayaan yang ada karena wanita diperlakukan secara tidak adil, dan menganggap laki-laki lebih prioritas beserta dengan kepentingan-kepentingannya. ${ }^{6}$

Dalam Islam sendiri gerakan feminisme dengan gagasan emansipasi berawal dari abad ke19 yang digagas oleh Rifah Tahtawi, Qasim Amin, dan Muhammad Abduh yang merupakan tokoh-tokoh intelektual islam Mesir. Perlunya peran partisipasi dan keikutseraan wanita dalam perjuangan untuk memajukan umat islam.

6 Ajeng Tiara Asih and Nailul Fauziah, "Hubungan Antara Kontrol Diri Dengan Kecemasan Jauh Dari Smartphone (Nomophobia) Pada Mahasiswa Jurusan Ilmu Komunikasi Fakultas Ilmu Sosial Dan Politik Universitas Diponegoro Semarang," Empati 6, no. 2 (2018): 23, https://ejournal3.undip.ac.id/index.php /empati/article/view/19725. 


\section{Muhammad Munir, Dwi Putri Robiatul Adawiyah}

Penumbuhan kesadaran terhadap persoalan gender untuk melepaskan diri dari budaya dan sistem patriarki yang menekan kebebasan wanita ini, pertama kali dicetuskan oleh wanita-wanita seperti, Zainab Fawwaz, Aisyah Tamuniah, Rokeya Sakhwat Hosein. $^{7}$

Gerakan feminisme Islam mulai berkembang pesat pada abad ke-20 yang berakar pada alquran yang menekankan pada aspek kesetaraan yang selama ini telah tersingkirkan oleh sistem patriarki. Feminisme Islam ini pada awalnya dipelopori oleh wanita-wanita Mesir seperti Zainab al Ghazali, Nabawiyya Musa yang memiliki tujuan untuk mencari kebenaran makna dari AlQuran. Untuk selanjutnya

7 M. (ed.) Mardinsyah, Hermeneutika Feminisme Reformasi Gender Dalam Islam Dalam Budby Munawar Rabman, Islam Dan Feminisme: Dari Sentralitasme Kepada Kesetaraan, Dalam Membincang Feminisme Diskursus Gender Perspektif Islam Dalam Mansur Faqib (Ed) Membincang Feminisme Diskursus (Surabaya: Risalah Gusti., 1995), 201. perkembangan feminisme Islam masuk ke bidang tafsir Alqur'an dengan melakukan penafsiran $\mathrm{Al}$ quran dengan pendekatan hermeneutika feminisme. ${ }^{8}$

Di Indonesia sendiri gerakan feminisme masih sering diperdebatkan. Feminisme yang dimaksudkan di sini adalah aliran yang memperjuangkan keadilan bagi wanita. Dan seperti yang diketahui feminism memilki bermacam-macam aliran., dari berbagai macam aliran ini ternyata pada zaman Kartini terpengaruh faham feminisme liberal. Kelompok ini berasumsi bahwa ketidakadilan muncul karena faktor hukum atau aturan yang mengatur masyarakat. Wanita dalam posisi subordinat (bawahan), untuk meningkatkan kedudukan wanita mereka harus di didik.' Selain itu prempuan

\footnotetext{
${ }^{8}$ N. Ismail, Perempuan Dalam Pasungan Bias Laki-Laki Dalam Penafsiran. (Bantul, Yogyakarta: LKiS Yogyakarta., 2003).

9 N Murniati, Getar Gender. (Yogyakarta: IKAPI., 2004).
} 
ditempatkan pada pekerjaan domestic atau rumah tangga, yang mana pekerjaan tersebut tidak menghasilkan uang serta tidak berharga.

Dalam patriarkial wanita dianggap lemah, pasif dan emosional serta dianggap tidak layak untuk mendapatkan kesempatan yang sama dengan laki-laki untuk masuk dalam dunia yang menjadi perhatian publik, sedangkan laki-laki sendiri dianggap kuat, rasional serta aktif. gerakan feminisme lahir untuk mencoba mengubah situasi ini. Wanita dan laki-laki tidak hanya dilihat dari kelaki-lakiannya ataupun kewanitanya, namun dilihat lebih umum lagi sebagai manusia. Laki-laki dan wanita sebagai sebuah agen keadilan dan kebenaran yang memiliki peluang dalam membangun peradaban yang sama. Konsep yang menjadi paradigma ini difokuskan kepada pemahaman yang komprehensif terhadap wilayah peran yang akan diambil itu sendiri. Jika wanita memfokuskan diri dalam peran domestik, tidak berarti ia harus meninggalkan peran publiknya, demikian juga sebaliknya. ${ }^{10}$

Dalam pengamatan awal peneliti, kesetaraan ini telah diterapkan salah satu kesetaraan yang telah diterapkan yaitu pada wanita pekerja karet yang ada di desa Kuala Mandor B kabupaten Kuburaya. Wanita muslimah yang ada di sana jarang untuk melakukan interakasi dengan anaknya karena mereka selalu sibuk untuk melakukan pekerjaan di luar rumah, pekerjaan noreh (melukai pohon karet) mereka mengerjakannya di tengah malam dengan membawa obor di

${ }^{10}$ N Said, Perempuan Dalam Himpitan Teologi Dan HAM Di Indonesia., Cet I (Yogyakarta.: Pilar Media, 2005). 


\section{Muhammad Munir, Dwi Putri Robiatul Adawiyah}

kepalanya dan memasuki kebun karet yang jauh dari keremaian dan hanya hutan-hutan. Pekerjaan demikian dilakukannya sendiri terkadang juga ada orang yang juga melakukan aktivitas yang sama di sebelah mereka tetapi berjarak sekitaran 100 meter.

Peneliti bawa ke ranah yang lebih ekstrim yang terlepas dari pola asuh anak tadi, keberanian mereka dalam melakukan noreh di tengah malam, di dalam hutan terkadang sendiri pekerjaan ini sangat membuat peneliti kagum sehingga menarik untuk di angkat dalam sebuah penelitian ini agar semua wanita muslimah memahami begitu berat kehidupan seorang muslimah yang terjadi di desa tersebut.

Dengan temuan awal di atas membuat peneliti mengangkat sebuah tema yang menitikberatkan kepada bagaimana wanita muslimah yang sebenarnya sedangkan yang terjadi kepada wanita muslimah di desa Kuala
Mandor B sangatlah sulit untuk menjadi muslimah yang sejati yang bisa setiap malam dalam dakapan dan pelukan seorang anaknya. Maka penelitian ini berjudul "Potret diri Wanita Muslimah : Studi Fenomenologi wanita pekerja karet di desa kuala mandor B kabupaten kuburaya"

Dalam penelitian ini terdapat beberapa kesamaan dari penelitian sebelumnya antara lain :

Pertama, penelitian yang tulis oleh Ade Kusuma (2018). Hasil dari penelitian ini menampilkan bahwa resolusi film hijab dan super didi tokohnya yang memiliki pekerjaan ganda yang dialami perempuan sedangkan hanya mendapatkan bagian pada sebuah domistikan. Peran tokoh perempuan pada film ini memberikan sebuah bukti kesholehah seorang perempuan. Perempuan perkotaan mengaktualisasikan kemandiriannya melalui sebuah bukti mandiri yang dilakukan oleh 
Vol. 13, No. 2, Oktober 2020

p-ISSN:2086 -0749

e-ISSN:2654-4784

seorang perempuan. Selain dari hal itu terdapat sebuah tuntuan yang berupa ekonomi di masayarakat urban yang bisa menjadikan perempuan bekerja ganda. ${ }^{11}$

Kedua, penelitian lain juga dilakukan oleh Robiatur Rosyidah (2016). Hasil dari penelitian ini menceritakan potret seorang wanita sholehah yang menjadi yang di pemerannya adalah Reem. Dalam novel ini terdapat delapan karakter wanita sholehah yang tergambar pada tokoh Reem yaitu: a) Inget kepada Allah, b) taat kepada kedua orang tua, c) sabar, d) ramah, e) tawakkal, f) mengedepankan kenting umum dari pada kepentingan diri sendiri,

11 A Kusuma, "Potret Gender Harmoni Pada Keluarga Urban," Jurnal Ilmu Komunikasi 1, no. 1 (2018), https://doi.org/doi: 10.33005/jkom.v1i1.9. g) salalu inget kematian, h) hafidzoh qur'an. ${ }^{12}$

Ketiga, penelitian yang dilakukan oleh Anita (2016) hasil dari penelitian ini mengungkapkan makna pesan yang ada pada iklan sampo-sampo. Dalam penelitian ini juga mengungkapkan citra diri wanita muslimah yang di unkapkan lewat iklan sampo bahwa wanita muslimah juga bisa berpenampilan sederhana. ${ }^{13}$

Perbedaan dari penelitian ini adalah mengungkapkan potret diri wanita muslimah yang ada di desa kuala mandor B kabupaten Kuburaya yang terjadi pada wanita pekerja karet. Pekerjaan ini

12 R Rosyidah, "Potret Wanita Sholehah Dalam Novel (Analisis Wacana Sara Mills Tentang Sosok Wanita Sholehah Dalam Novel)." (Universitas Islam Negri Sunan Gunung Djati Bandung., 2018).

13 Anita, "Citra Wanita Muslimah Dalam Iklan Di Televisi (Analisis Semiotika Terhadap Iklan Sampo Rejoice Dan Sampo Sunsilk)." (Universitas Islam Negeri Walisongo., 2016). 


\section{Muhammad Munir, Dwi Putri Robiatul Adawiyah}

dilakukan di malam hari mulai dari jam 01-09 WIB. Keunikkan dalam penelitian ini ialah keberanian wanita muslimah berada kebun karet dalam waktu malam dan jauh dari sebuah keramaian.

Dalam penelitian tentang potret diri wanita muslimah maka peneliti menggunakan jenis penelitian kualitatif deskriptif dan pendekatannya Studi Fenomenologi, dengan menggunakan metode pengumpulan data: wawancara, observasi dan dokumentasi, yang meliputi wanita muslimah, wanita pekerja karet, serta masyarakat yang termasuk yang ada di desa tersebut. Adapun lokasi penelitian ini bertempat di kecamatan Kaula Mandor B Kabupaten Kuburaya dengan cara snowball. Dengan pertimbangan bahwa masyarakat Kuala Mandor khususnya wanita banyak yang bekerja karet dan menjadi ibu rumah tangga, yang mana wanita muslimah berperan penting dalam sebuah kesuksesan berkeluarga seperti pola asuh anak, bisa taat kepada suami dan kepada orang tuanya. Sedangkan dalam analisis data peneliti akan menganalisis, mengeksplorasi data, menganalisis data untuk menjawab pertanyaan penelitian atau menguji hipotesis penelitian, menampilkan dan memvalidasi data. analisis data diarahkan pada pertanyaan penelitian, reduksi data, sintesisasi. Triangulasi dan perpanjangan keikutsertaan sebagai pengecekan keabsahan data.

\section{Pembahasan}

\section{Peran Wanita Muslimah}

Peran muslimah yang ada di kecamatan kuala mandor B sangat butuh banyak pengorbanan karena mereka harus membagi waktu kapan harus kerja, mengasuh anak, ikut pengajian dan arisan ibu-ibu. Seperti yang dialami seorang ibu (JR, 40) yang berkerja karet, bekerja sebagai dagang sayur-sayuran dan buah-buah yang 
Vol. 13, No. 2, Oktober 2020

p-ISSN:2086 -0749

e-ISSN:2654-4784

di jual kepasar. Mulai dari jam 1 malam ibu tersebut berangkat dari rumahnya setelah melakukan sholat tahajjud, ibu tersebut mulai meninggalkan seorang anak yang sedang berumur 2 tahun, ibu tersebut memiliki 4 orang anak dan salah satu dari anaknya ada yang sedang kuliah s2 di salah satu perguruan tinggi islam negri di Jawa Timur. Pekerjaan ini beliau lakukan setiap hari apabila dalam keadaan muslim kemarau apabila musim hujan dia ganti dengan pekerjaan di sawah dan pekerjaan yang bisa membantu membiayai anak dan keluarganya.

Pekerjaan ini beliau kerjakan hampir kurang lebih 20 tahun. Banyak cerita sedih yang diceritakan oleh ibu tersebut salah satunya ialah ketika bertemu dengan orang tidak jelas yang ada di tengah-tengah kebun yang hanya ada sebuah obor/senter di kepala. Kisah lainnya ialah ketika bertemu dengan ular besar yang ada di tengah-tengah hutan. Bahkan ibu tersebut pernah mengajak salah satu anaknya untuk pergi kekebun jam 1 malam agar bisa menemaninya karena perasaan takutnya. Cerita lainnya seperti terkena hujan ketika malam hari dalam keadaan bekerja yang mana ketika turun hujan maka gagallah hasil torehannya (melukai pohon karet). Peran inilah yang beliau emban sebagai wanita yang tangguh dalam bekerja membiayai seorang suami dan anak-anaknya.

Dalam peran inilah seorang ibu tersebut menjadi multi talenta seperti dalam mengasuh seorang anaknya, mengikuti acara muslimatan di kampunganya. Beliau rasakan hal yang biasa saja karena sudah menjadi kebiasannya setiap hari. Perkerjaan ini tidak 


\section{Muhammad Munir, Dwi Putri Robiatul Adawiyah}

hanya ibu ini saja ada banyak wanita lainya yang menghidupi keluarganya dengan mengorbankan separuh waktu istirahatnya demi mendapatkan sebuah nafkah. Ibu (AS, 34) dia memiliki 2 orang anak dan salah satu dari anaknya ada yang sedang kuliah s1 di salah satu perguruan tinggi di Jawa Timur. Berbeda dengan ibu (JR) tadi, ibu (AS) ini sebagai kepala keluarganya karena sudah lama ditinggalkan oleh suaminya, yang mana beliau juga harus melakukan pekerjaan yang sama demi memberikan nafkah kepada anak-anaknya dan keluargnya. Beliau juga terkenal aktif dalam sebuah pengajian muslimatan yang diadakan setiap hari rabu. Dalam berpakaian sehari-hari ibu tersebut sangatlah muslimah karena dulunya pernah pergi ke Arab Saudi sebagai TKW.

$$
\text { Dalam membahas peran }
$$
wanita muslimah tidak terlepas dari peran Islam juga, dahulu zaman jahiliyah wanita dianggap sebagai manusia lemah dan tidak memiliki sebuah manfaat apa-apa, bahkan hanya bisa memberikan sebuah kepuasan kepada laki-laki, dan seorang wanita tidak ada peran bagi wanita. Para ayah zaman dahulu malu ketika memiliki anak wanita. Untuk menutup rasa malunya mereka melakukan pekerjaan yang tidak manusiawi seperti membunuh bahkan mengubur hidup-hidup anak wanitanya. ${ }^{14}$ Seperti itulah kebencian orang-orang dahulu kepada wanita, hal ini pernah dilakukan Khulafah Ar Rosyidin Umar bin Khattab sebelum ada dalam naungan agama islam, pekerjaan ini juga Allah abadikan dalam Al-Qur'an.

Pada praktik pembunuhan kepada wanita tentunya Allah mengecam tindakan tersebut. ${ }^{15}$

14 M Samad, Pemberdayaan Perempuan Muslimab: Status, Fungsi Dan Peran Wanita Islam Dalam Era Globalisasi. (Riau: Yayasan Pusaka Riau., 2001). 13

15 S. Musdah, Membangun Surga Di Bumi Kiat-Kiat Membina Keluarga Ideal Dalam Islam., 2011. 18 
Vol. 13, No. 2, Oktober 2020

p-ISSN:2086 -0749

e-ISSN:2654-4784

Kedatangan Nabi Muhammad kedunia untuk memberikan rahmatan lil alamin kepada semua manusia, khususnya wanita. Dari sini lah di mulainya khittah dan budaya baru yang memberikan porsi kepada kemerdekaan wanita serta hak-hak sebagai masyarakat. Martabat wanita menjadi terkenal dengan dengan sikap yang lemah lembut. Sifat ini Allah abadikan dalam Al-Qur'an dan hadits-hadits Rasulullah SAW.

Kedatangan

Islam

menorehkan sejarah yang dibuktikan dalam gerakan femenisme serta nabi sendiri telah mempelopori emansipasi para wanita yang di mulai dari kelurga dan istri-istri dan putrinya, setelah itu juga dilanjutkan oleh para sahabat-sahabat nabi. Sejak masa kejayaan islam memberikan sebuah contoh istri, putri, sahabat rasulullah serta para tabi'in. Salah satu contoh yang bisa kita ambil uswah hasanah dari para wanita bagaimana mereka berperilaku, mengurus suami, mengasuh anak dan keluarga, membimbing rumah tangga, bekerja diluar rumah, potret diri ketika ada di keramaian serta permasalah yang ada dalam kehidupan keluarga. ${ }^{16}$

\section{Wanita dalam lingkup Islam}

Nilai-nilai kemanusiaan ini tentunya pada hakikatnya terkandung pada agama Islam. Salah satu yang menjadi aspek penting terhadap kesatuan dan kesamaan pada manusia merupakan satu bentuk yang menjadi perpaduan dari nilai-nilai kemanusiaan. Pada hakikatnya tujuan dari Islam sendiri yakni memanusiakan manusia, mendidik manusia agar menjadi baik dalam

16 Jamhari, Citra Perempuan Islam: Pandangan Ormas Keagamaan. Jakarta: Gramedia Pustaka Utama bekerjasama dengan PPIM-UIN dan the Ford Foundation., 2003), 4. 


\section{Muhammad Munir, Dwi Putri Robiatul Adawiyah}

berbagai aspek, fisik, spiritual, moral serta aspek sosialnya. Terlebih penting lagi yang menjadi dasar dan keharusan yaitu menghormati manusia dengan tidak melihat jenis kelamin sosial (gender), ras, suku-bangsa, dan sebagainya. Banyak sekali ajaran Islam tentang ketuhanan dan kemanusiaan. Pada aspek yang pertama ini berisi beberapa kewajiban manusia kepada Allah, untuk yang kedua berisi beberapa aturan yang mengatur hubungan sesama manusia. ${ }^{17}$

Masalah kemanusiaa yang terjadi salah satunya terjadinya peperangan dan perselisihan di masa Rasulullah pada muslimin dan orang non muslim, peran wanita sangatlah mulia yang mendampingan laki-laki dalam membantu para rakyat yang terkena musibah serta yang mengalami luka. Justru yang memberikan arahan kepada kaum

\footnotetext{
17 A. Hamid M Djamil, Seperti Inilah Islam Memuliakan Wanita. (Jakarta: PT Elex Media Komputindo, 2016), 45.
}

laki-laki yakni dari kaum wanita sehingga memilik keberanian dalam berperang. Wanita pertama yang memberikan komandu serta semangat dalam berperang padahal pada waktu itu rasulullah sedang merasakan sebuah ketakutan sampai gemetar seluruh tubuhnya seperti ketika bertemu dengan malaikat pemberi wahyu yaitu malaikat Jibril wanita tersebut bernama Siti Khadijah. ${ }^{18}$

Dalam sejarah Islam di Kordova Andalusia (Spanyol), pencapaian sebuah kejayaan islam pada tahta yang tinggi, tidak terlepas dari peran kaum wanita karena pada masa tersebut wanita setara dengan kaum laki-laki dalam membela sebuah negara. Karena pada masa tersebut Andalusia di pimpin oleh Raja Abdurrahman Al Nashru serta istri yang memiliki sebuah kecerdasan dan bijak. Sedangkan wanita hebat yang ada di

${ }^{18}$ Y Qardhawi, Fiqih Jihad. (Bandung: Penerbit Mizan., 2010), 87. 
Vol. 13, No. 2, Oktober 2020

p-ISSN:2086 -0749

e-ISSN:2654-4784

Indonesia ialah Raden Ajeng Kartini. Beliau pernah menjadi pemimpin pasukan armada laut dalam melawan Belanda, Siti Rohana Kudus, Rangkayo Rasuna Said, Tjuk Nya' Dien dan wanita muslimah lainnya. Inilah peran sosial yang pernah dipimpin oleh para wanita muslimah yang hebat dari indonesia mereka tidak hanya aktif di rumah saja melainkan turun kedalam medan perang. Tetapi sebagai wanita muslimah mereka tidak melepas sebuah tanggung jawab dalam mengurus keluarganya. ${ }^{19}$

Keistimewaan wanita Allah berikan kepada wanita yang tertulis didalam Al-Qur'an yakni An Nisa. Peran wanita sangatlah berguna dalam sebuah kehidupan. Antaranya melahirkan manusia

${ }^{19}$ R. Nuryanti and B Akob, Perempuan Dalam Historiografi Indonesia (Eksistensi Dan Dominasi). (Sleman: CV Budi Utama., 2019), 17. manusia hebat, membimbing anak, manajemen kebutuhan pokok keluarga. Peran wanita memberikan sebuah sumbangsi kemanusia bukan sebuah tenaga atau kekuatan saja. Begitulah islam memberikan sebuah keistimewaan kepada wanita. ${ }^{20}$

\section{Kesamaan Derajat Patriarki dan Femenisme di Hadapan Allah}

Jika laki-laki diperbolehkan untuk melakukan suatu pekerjaan di luar rumah tentunya wanita juga sama boleh untuk melakukan aktivitas serta kerja di luar rumah tetapi tidak terlepas izin dari suaminya. Hal ini telah tercemin oleh kegiatan yang dilakukan oleh wanita pekerja karet yang ada di kecamatan Kaula Mandor B Kabupaten Kuburaya yang mana sehari-harinya melakukan kegiatan

${ }^{20}$ S Quț, Tafsir Fi Zhilalil Qur an Jilid 5. (Beirut: Darusy-Syuruq., 1992), 56. 


\section{Muhammad Munir, Dwi Putri Robiatul Adawiyah}

torehannya (melukai pohon karet).

Tentunya tak luput dari kegiatan sehari-harinya yang masih mengurus suami serta anakanaknya.

Penciptaan manusia Allah memberikan dua manusia yang berbeda. Perbedaan ini bukan hanya dari perbuatan. Penciptaan surga pun tidak dijadikan hanya untuk laki maupun wanita. Semua manusia dihadapan allah sama, baik itu raja, pemerintah, kaya, miskin dan lain-lain. Semuanya hanya sebagai hamba Allah yang nantinya dimintai sebuah pertanggung jawaban atas dirinya. Pandangan mengenai kesetaraan manusia dengan manusia lainnya ini telah diawali oleh pandangan akan keyakinan yang menyangkut pada Allah, yang mana tidak ada satu pun yang dapat setara dengan Allah serta Allah tidak memiliki anak amupun titisan. Dalam hal ini tentunya mengandung makna tiada satupun manusia yang boleh dipertuhankan yang dimaksud disini dijadikan tujuan dari hidup, disembah, ditakuti serta dianggap benar keseluruhannya. ${ }^{21}$

Manusia pada hakikatnya sama, tidak ada yang menjadi nomor satu ataupun nomor dua. Dalam diri Rasulullah terdapat kekuatan tauhid sehingga membuat beliau berani membela kebenaran, membela yang teraniaya serta membela yang telah direndahkan seperti yang terjadi pada kaum wanita,anak-anak, budak serta kelompok yang rentan lainnya yang menutupi kezaliman para penguasa dengan nama Tuhan untuk menutupinya. Hal ini terlihat, tauhid tidak hanya sekedar membahas permasalahan agama saja, melainkan dapat menempatkan segalanya sesuai posisi, menempatkan dalam hal ini Tuhan sebagai Tuhan, serta manusia pada posisi manusia. Jika hal ini telah melekat pada kejiwaan seseorang akan menyebabkan

${ }^{21}$ M. I. al-Din Tawfiq and S Narulita, Panduan Lengkap \& Praktis Psikologi Islam. (Depok: Gema Insani., 2006), 13. 
Vol. 13, No. 2, Oktober 2020

p-ISSN:2086 -0749

e-ISSN:2654-4784

seseorang tersebut bebas dari ketidakadilan, diskriminasi, penindasan, rasa takut, dan membawa manusia pada keselamatan dan kemaslahan tidak hanya dalam aspek individu melainkan pada tatanan masyarakat yang santun, manusiawi serta bermoral, ajaran demikianlah yang telah dibawa serta diterapkan oleh Rasulullah Muhammad Saw. 22

Kezaliman dan pemberhalaan (thaghut) inilah dapat dibebaskan dari belenggu manusia dengan tauhid. Serta telah menghapus segala hal mengenai diskriminasi dan subordinasi. Manusia memiliki tugas sebagai khalifah di bumi, salah satu tugas dari manusia adalah menjaga kesejahteraan, kemakmuran, kedamaian serta membawa kemuliaan pada alam semesta ini

\footnotetext{
22 Murniati, Getar Gender., 24.
}

(rahmatan lil alamin). Untuk mencapai tujuan tersebut tentunya dibutuhkan kesadaran akan penegakan kebenaran, mencegah hal-hal yang buruk terjadi dan mendorong untuk hal-hal yang baik.

Ketika melakukan semua tugas-tugas tersebut tidak mungkin dilakukan oleh satu jenis kelamin manusia, melainkan dilakukan oleh kedua jenis kelamin manusia. Laki-laki dan wanita telah mendapatkan perintah oleh Allah untuk saling tolong menolong, bekerjasama serta mendukung untuk melakukan amar makruf nahi mungkar untuk menjaga dunia yang baik, indah dan benar di bawah naungan serta ridha Allah Swt. Sesuai dengan firman Allah Swt. dalam Al-Quran.

Jika dilihat dari konteks katanya, dalam bahas Arab kata 


\section{Muhammad Munir, Dwi Putri Robiatul Adawiyah}

"khalifah" tidak dikhususkan merujuk pada satu jenis kelamin tertentu maupun satu kelompok saja. Untuk itu posisi laki-laki dan wanita memiliki tugas, peran serta fungsi yang setara, di pertanggungjawabkan di hadapan Allah Swt.

Dalam mempertanggungjawabkan tersebut baik posisi sebagai hamba maupun khalifah poin pentingnya adalah ketakwaan, tidak dari keturunan, jenis klamin tertentu atau kelompok suku tertentu. ${ }^{23}$

Pada kasus ini pekerja wanita di kecamatan Kaula Mandor B Kabupaten Kuburaya telah berusaha untuk mendapatkan posisi dan pekerjaan yang setara dengan laki-laki, wanita selalu diidentikkan dengan hal yang berbau gender. Pembagian peran yang terjadi ini dapat menyebabkan konstruksi sosial. Wanita sebagai sesama

\footnotetext{
${ }^{23}$ Musdah, Membangun Surga Di Bumi Kiat-Kiat Membina Keluarga Ideal Dalam Islam., 10.
}

manusia tentunya memiliki perasaan, pendapat dan pemikiran yang perlu untuk diakui setara dengan laki-laki, hal ini dikarenakan terjadi penyangkalan selama berabad-abad lalu. ${ }^{24}$

Di kehidupan yang berkembang dalam masyarakat gender sebagai dasar yang membedakan perilaku, peran, karakteristik emosional serta mentalitas yang ada pada laki-laki dan wanita. Faktor-faktor nonbiologis, emosi, mentalitas, perilaku, nilai serta sosial budaya ini merupakan dasar untuk mengetahui perbedaan laki-laki dan wanita. Walaupun anggapan pada sifat feminin yang dimiliki wanita dan maskulin yang dimiliki laki-laki tidak bisa dijadikan tolak ukur permanen dalam membedakan tugas serta perannya. Terkadang masyarakat menganggapnya mutlak seperti halnya keadaan biologisnya. Untuk

\footnotetext{
24 A. Rokhmansyah, Pengantar Gender Dan Feminism. (Yogyakarta: Garudhawarca., 2016), 15.
} 
Vol. 13, No. 2, Oktober 2020

p-ISSN:2086 -0749

e-ISSN:2654-4784

itulah adanya wanita-wanita pekerja karet yang berani tersebut dapat membantah permasalahan gender yang ada dalam masyarakat yang menganggap wanita hanya bisa bersikap feminine saja.

\section{Keberanian Wanita Muslimah}

Keberanian wanita muslimah yang terjadi di desa ini ialahnya melakukan pekerjaan diluar rumah ketika jam 01.00 malam hal ini menjadi sebuah keberanian bagi wanita muslimah yang hanya dilakukan dengan sendirian di tengah-tengah kebun karet. Seperti yang terjadi dengan ibu (JM, 34) yang melakukan pekerjaan ini sendirian. Beliau sangat berhati-hati dalam memasuki perkebunan tersebut. Menurutnya pekerjaan ini adalah sebuah kebiasaannya yang sudah lama ia lakukan, kalau perasaan takut pasti tapi terkadang ketakutannya ketika melakukan pekerjaan tersebut hilang karana yang beliau pikirkan adalah keluarganya di tambah lagi beliau memiliki seorang anak yang masih berumur 1 tahunan.

Sedangkan yang terjadi dengan ibu (SH, 40) dan Ibu (MA, 45) mereka berdua adalah orang yang menengah keatas menurut materi cukup dalam menafkahi keluarganya. Menurut pekerjaan ini beliau lakukan hanya tidak ingin membiarkan kebunnya kehilangan karetnya pekerjaan ini biasanya beliau lakukan ketika jam 03.00 saja sebagai pekerjaan sampingan saja. Begitu juga dengan ibu (MA) kebun yang sangat banyak dan tidak ada yang mau mengerjakan lagi kecuali ibu tersebut. Berbeda dengan seorang gadis yang berumur sekitar 26 tahunan beliau ialah (SL, 26) yang melakukan pekerjaan ini di tengah malam demi membiayai 


\section{Muhammad Munir, Dwi Putri Robiatul Adawiyah}

keluarganya dan juga membiayai dirinya sendiri, meskipun beliau adalah seorang guru TK ketika pagi hari. Menurut peneliti pekerjaan ini adalah pekerjaan yang sangat ekstrim, karena jarang sekali kita temukan dalam kehidupan seorang wanita.

Ketika masa Rasulullah Saw. Banyak wanita yang mencapai derajat ketakwaan yang tinggi. Wanita yang mati syahid untuk pertama kalinya sejarah mencatat adalah bernama Sumayyah. Dalam hal keimanan juga yang pertama kali percaya dan beriman dan mengakui kenabian Nabi Muhammad Saw. Yaitu Khadijah binti Kuwailid, yang merupakan istri dari Rasulullah Saw. Ditambah lagi Rasulullah menjadikan Aisyah sebagai Umm al-Mukminin tanpa ragu, beliau diakui akan kecerdasan serta keteguhan pendiriannya dalam beragama. Ditambah lagi, pada waktu Rasulullah dan Abu Bakar sahabatnya dikejar oleh orang kafir Quraisy dan bersembunyi di Gua Tsur. Seorang wanita bernama Asma' binti Abu Bakar tampil berani untuk mengantarkan kepada Rasulullah sampai pada mulut gua. ${ }^{25}$

Keberanian tersebut seperti menyerupai wanita pemberani yang mengikuti perang Uhud, terjadi pada 7 Syawal $3 \mathrm{H} / 22$ Maret 625 M. Beliau adalah Ummu Umarah yang membantu Rasulullah berperang sedangkan pada masa itu pasukan muslimin berjumlah 700 pasukan tentara, sedangkan tentara yang di pimpin Abu Sufyan berjumlah 3.000 tentara. Dalam perang ini kaum muslim menuai kekalahan karena para sahabat Rasulullah tidak mengdengar perintah Rasul-Nya. Tetapi dalam peperangan ini terdapat pejuang dari kalangan wanita yang bernama Ummu Umarah yang ingin mengimplementasikan

${ }^{25} \mathrm{~W}$ Zarman, Ternyata Mendidik Anak Cara Rasulullah Itu Mudah \& Lebih Efektif. (Bandung: Ruang Kata., 2011), 54. 
Vol. 13, No. 2, Oktober 2020

p-ISSN:2086 -0749

e-ISSN:2654-4784

keislamannya dalam kehidupan yang nyata pada saat itu.

Keberanian dalam mengambil sebuah keputusan karena dia melihat pasukan muslimin sedang dalam keadaan tidak aman maka Ummu Umarah langsung membantu pasukkan muslimin sampai akhirnya terluka. ${ }^{26}$

Dari hal tersebut telah menjabarkan beberapa dari sejarah tentang wanita-wanita yang telah tampil berani yang telah mencapai derajat yang tinggi dalam Islam. Hal tersebut telah membuktikan tidak sedikitpun Islam membedakan seseorang berdasarkan jenis kelaminnya. Jika ditarik dengan kasus yang telah dilakukan di kecamatan Kaula Mandor B Kabupaten Kuburaya telah sesuai dengan konsep serta contoh sejarah yang ada di Islam,

26 Abdul Latip Talib, Perang Uhud: Catatan Duka Tentera Islam. (Selangor: PTS Litera Utama., 2010), 23. wanita dengan keberaniannya untuk menegakkan segala sesuatu yang benar. Selanjutnya akan dilihat mengenai gambaran pola asuh anak dari wanita muslimah.

\section{Pola Asuh Anak Wanita}

\section{Muslimah}

Pekerja karet yang terjadi pada wanita muslimah di desa Kuala Mandor B memberikan sedikit kesempatan dalam mengasuh anak. Akan tetapi mereka memiliki cara tersendiri dalam mengasuh anaknya. Seperti yang terjadi pada ibu (JR) 20 tahun lamanya beliau melakukan pekerjaan ini, yang setiap harinya meninggalkan anak dan suaminya dalam keadaan tertidur. Tetapi beliau bisa membiayai anaknya bahkan ketiga anaknya pernah mondok di salah satu pesantren di Jawa Timur pekerjaan yang beliau lakukan sangat berat tetapi tujuannya beliau adalah agar anak- 


\section{Muhammad Munir, Dwi Putri Robiatul Adawiyah}

anaknya tidak sama dengan beliau.

Menurutnya dalam pola asuh anaknya ialah mengajarkan segala bentuk kesederhanaanya yang kerjakan adalah pekerjaan yang berat dan tidak semua orang bisa melakukannya.

Berbeda dengan ibu (JM) yang menitipkan anaknya kepada tetangganya selama dia bekerja. Alasannya agar dia tidak kesepian dan tidak menghawatirkan apalagi anaknya masih berumur 1 tahun. Peniliti juga menegaskan mengapa yang dijadikan objek adalah seorang wanita karena seni dalam menoreh karet sangatlah kreatif. Karena dalam pekerjaan ini butuh sebuah kehati-hatian apabila menyentuh hati dari pohon tersebut maka yang terjadi ialah aliran karetnya mengurang.

Wanita merupakan seorang ibu yang mana ia merupakan seorang guru, pengatur semua tanggungjawab yang ada di keluarga serta tempat pertama seorang anak untuk belajar sesuatu, begitulah pandangan Islam mengenai seorang ibu. Semua tanggung jawab muali dari mengurus keperluan suami dan anak-anak sampai pada menyediakan hidangan makanan dan minuman sampai pada menyiapkan keperluan pakaian dan urusan rumah tangga lainnya. ${ }^{27}$

Dalam hal pengasuhan seorang anak, tentunya melibatkan peran kedua orang tua, baik itu ayah maupun ibu. Baik itu untuk masalah keimanan, mental, fisik, kekejiwaan serta sampai pada masalah seks yang merupakan tanggungjawab orang tua untuk memberikan pemahaman kepada anaknya. Untuk mencapai masa depan yang cerah dibutuhkan seuatu pengasuhan yang baik oleh orang tua agar anak menjadi manusia yang nerakhlak, berkarakter serta menjadi generasi yang tangguh lagi pantang

\footnotetext{
27 Syarbini, Model Pendidikan Karakter Dalam Keluarga., 45.
} 
Vol. 13, No. 2, Oktober 2020

p-ISSN:2086 -0749

e-ISSN:2654-4784

menyerah. Pemahaman serta penetapan pola asuh orang tua yang sesuai pada tahap perkembangan anak berdasarkan syariah Islam yang diajarkan dan disunnahkan oleh Rasulullah Muhammad Saw. ${ }^{28}$

Islam menjadi semua solusi atas permasalahan yang terjadi, seperti salah satunya dalam hal mengasuh anak. Saat ini generasi muda bangsa Indonesia sedang mengalami krisis akhlak, yang mana kondisi ini jauh berbeda dengan keadaan dulu, untuk itu diperlukan suatu arahan kepada anak yang sesuai ajaran Islam agar anak memiliki akhlak yang mulia. Terdapat beberapa tahap perkembangan anak, salah satunya masa yang paling penting bagi seorang anak yaitu masa keemasan (golden age) masa ini merupakan

28 Zarman, Ternyata Mendidik Anak Cara Rasulullah Itu Mudah \& Lebih Efektif., 25. kunci dari pembentukan karakter anak, keberhasilan dalam pengasuhan di masa golden age dapat menjadi penentu pada masa remaja dan dewasanya serta menjadikannya seseorang yang dapat berguna bagi nusa dan bangsanya. ${ }^{29}$

Al-Qur'an dan sunnah menjadi dasar dari pola asuh Islam mulai dari mendidik, membiasakan sampai pada membimbing anak dengan tetap berpegang pada suatu kesatuan utuh dan bagaimana orang tua memperilakukan anaknya ketika masih kecil. Pemahaman orang tua mengenai perkembangan anaknya mulai dari masalah akidah, akhlak, kemampuan fisik, motorik, sosial emosi sampai pada kemampuan akademiknya diperlukan agar orang tua

\footnotetext{
${ }^{29}$ S Ikhsan, Jurus Jitu Mendidik. Anak. Dalam Kandungan Secara Islami. (Jakarta: PT Elex Media Komputindo., 2019), 54.
} 


\section{Muhammad Munir, Dwi Putri Robiatul Adawiyah}

mengetahui kemampuan yang ada dalam diri anak. Serta dapat membekalinya dengan pemahaman yang berlandaskan pada Islam. ${ }^{30}$

\section{Sunnah dari Rasulullah}

Saw. Dalam hal mendidik anak ini terbagi menjadi empat tahap antara lain: ${ }^{31}$

\section{Usia anak 0-6 tahun}

Dalam tahap ini, Rasulullah menyuruh kita untuk memposisikan anak sebagai raja, memberikannya kasih saying, mengasihi serta memanjakan anak. Kasih saying yang adil kepada setiap anak-anaknya. Untuk membuat anak-anak menjadi dekat dengan orang tua (ibu dan bapak) maka berikan rasa aman pada mereka, tidak memukul anak

$30 \mathrm{~W}$ Waston and M Rois, "Pendidikan Anak Dalam Perspektif Psikologi Islam (Studi Pemikiran Prof. Dr. Zakiyah Daradjat)," Profetika: Jurnal Studi Islam 18, no. 1 (2017): 27, https://doi.org/doi:

10.23917/profetika.v18i1.6298.

31 Y. al-Madanī Tabrīzī, Pendidikan Seks Untuk Anak Dalam Islam: Panduan Bagi Orang Tua, Guru, Ulama, Dan Kalangan Lainnya. (Jakarta: Pustaka Zahra., 2003), 45. karena mereka melakukan kesalahan ataupun dengan alasan untuk mendidik. Anak-anak akan merasa ditemani sekaligus merasa orang tuanya senantiasa berada disisi mereka sepanjang waktu.

\section{Usia anak 7-14 tahun}

Mulai pada tahap ini hendaknya ditanamkan nilai-nilai tanggungjawab serta disiplin anak. Sebagaimana hadits Abu Daud, "Perintahlah anak-anak kamu supaya mendirikan shalat ketika berusia tujuh tahun dan pukullah mereka karena meninggalkan shalat ketika berumur sepuluh tahun dan asingkanlah tempat tidur di antara mereka (lelaki dan wanita)." Makna dari pukullah disini hanya diperuntukkan agar anak-anak menjadi ingat dan bukan untuk menyiksa anak. Pada usia ini merupakan waktu yang tepat untuk menanamkan dan membangun kepribadian anak berdasarkan Islam. 
Vol. 13, No. 2, Oktober 2020

p-ISSN:2086 -0749

e-ISSN:2654-4784

\section{Usia anak 15-21 tahun}

Memperlakukan anak dengan mencoba menjadi kawan atau teman mereka merupakan hal yang hendaknya dilakukan pada tahap ini. Pada masa remaja ini anak akan dipenuhi oleh sikap berontak. Menjadi kawan dengan mendengarkan segala keluh kesah dan masalah yang mereka hadapi, tidak memarahi anak namun menggunakan pendekatan agar anak-anak tetap bahagia dan tidak mencari kebahagiaan dan kesenangan di luar rumah.

\section{Usia 21 tahun ke atas}

Tahap ini sepenuhnya kepercayaan diberikan kepada anak. Anak telah mengerti cara untuk bertanggungjawab serta arahan hidupnya. Kebebasan anak untuk membuat keputusan sendiri. Peran orang tua disini hanya menasehati, mengamati serta senantiasa mendoakan anak- anaknya agar sesuai dengan prinsip serta nilai-nilai islam. Sering menasehati anak merupakan hal yang harus dilakukan karena menasehati anak sebanyak 200 kali atau bahkan lebih akan merubah dan membentuk perilaku anak sesuai dengan yang orang tua inginkan.

Dengan demikian, senantiasa menjaga anak-anak agar terhindar dari siksa api neraka yang sesuai dengan ajaran dari agama Islam dan as-sunnah dan dikehendaki oleh Allah Swt.

\section{Analisis Teori Fungsional}

\section{Struktural}

Dalam poin ini peneliti mengkaitkan tiga point diatas dengan dengan teori fungsional struktural, yang kemudian dianalisis menggunakan teori ini. Fungsi dasar dalam teori ini adalah pengelompokan masyarakat berdasarkan fungsinya. Teori ini 


\section{Muhammad Munir, Dwi Putri Robiatul Adawiyah}

dikembangkan oleh Kingsely

Davis dan Wilber Moore yang menjelaskan

bahwa

pengelompokan sosial masyarakat itu sebagai kejadian yang umum akan tetapi sangat penting. Dalam anggapan Davis dan Moore tidak ada manusia yang terlepas dari pengelompokkan atau tidak memiliki kelas. Menurut Devis dan Moore pengelompokkannya berdasarkan fungsional dan semua masyarakat memerlukan pengelompokkan tersebut. Sistem pengelompokkan ini berguna sebagai sebuah jalan agar manusia tidak mengacu kepada individu tetapi juga sebagai kedudukkan begitulah anggapan dari Davis dan Moore. Pusat perhatian dalam masalah ini ada pada cara bagaimana kedudukkan bisa mempengaruhi kemampuan yang berbeda, dan juga tidak terpusatkan pada bagaimana individu memperhatikan sebuah masalah yang mereka miliki. ${ }^{32}$

32 E Novianti, Teori Komunikasi Umum
Berdasarkan

teori

fungsional struktural menurut Robert Merton terdapat dualistas yang terjadi pada laki-laki dan prempuan yang menunjukan bahwa mereka dalam naungan hierarki. Merton dalam Ritzer mengatakan bahwah laki-laki dan wanita memiliki sebuah peran yang saling melengkapi yang sesuai dengan kebutuhan pribadinya. Pada realit yang sesungguhnya seorang laki-laki yang menafkahi keluarga sedangkan istri yang mengasuh anak. $^{33}$

Merton juga mengkritik tiga postulat di dalam teori struktural. Pertama adalah postulat tentang bersatunya fungsi masyarakat. Sebuah budaya serta sosial yang sudah ada di dalam lingkungan masyarakat adalah sebuah fungsional untuk masyarakat itu

Dan Aplikasinya. (Yogyakarta: Andi Offset., 2019), 180.

33 George Ritzer, Teori Sosiologi Modern. Jakarta: Prenadamedia Grup., 2014), 131. 
sendiri untuk menyatukan masyakarat atau individu. Dalam pandangan Merton secara tersirat, walaupun hal ini di terima oleh masyarakat primitif atau masyarakat kecil, tetapi dalam pengaplikasiannya belum tentu di terima oleh masyarakat yang kompleks. Artinya walaupun budaya sebagai fungsional masyarakat, contoh di suatu daerah wanita wajib di rumah, tetapi di daerah lain ada yang mewajibkan wanita juga harus ikut bekerja. Karena dalam menerapkan sebuah sistem fungsional ini tidak mudah bagi masyarakat yang kelas sosialnya tinggi, atau punya pendirian yang kuat untuk tetap mempertahankan bahwa wanita wajib berkarir. ${ }^{34}$

Kedua adalah postulat fungsionalisme universal. Bahwa sebuah kultur dan sosial yang ada

\footnotetext{
${ }^{34}$ Ritzer, 132.
}

pada suatu lingkungan masyarakat memiliki sebuah fungsi yang positif. Tetapi dalam tanggapan Merton tidak setiap budaya, adat, gagasan, kepercayaan memiliki kekuatan yang positif. Misalnya nasionalisme fanatik sangat meruntuhkan suatu negara karena menjadikan tidak fungsional dalam sebuah perkembangan senjara nuklir. Artinya walaupun kurltur pada sebuah negara atau pada sebuah daerah berfungsi sangat baik, tetapi masih memiliki fungsional yang fanatik kepada lingkungannya itu sama dengan tidak ada. ${ }^{35}$

Ketiga adalah postulat indispensabilitiy. Maksudnya adalah semua elemen masyarakat yang melekat pada sebuah budaya tidak hanya memiliki sebuah sifat yang positif tetapi juga

35 George Ritzer, Teori Sosiologi Modern (Jakarta: Kencana Prenadamedia group, 2014), 132. 


\section{Muhammad Munir, Dwi Putri Robiatul Adawiyah}

memberikan cerminan yang sangat

diperlukan bagi masyarakat untuk mencapai sebuah kebersamaan. Postulat ini mengarahkan kepada masyarakat agar semua struktur dan fungsional yang ada dimasyarakat menjadi satu untuk masyarakat. Tidak ada pembatas, pembeda antara struktural dan fungsional yang bekerja samasama baiknya. Sedangkan Parson mengkritik Merton bahwa di dalam masyarakat terdapat banyak variatif dalam struktural dan fungsional ini sebenarnya menjadi alternatif yang harus ditemukan di dalam masyarakat. Artinya semua gender masyarakat boleh melakukan sebuah pekerjaan di luar rumah baik laki-laki maupun wanita. ${ }^{36}$

Dari ketiga ini sebenarnya menurut Merton adalah pernyataan non-empiris yang membutuhkan ujian dari kajian sosiologi agar dapat mengembangkan sebuah paradigma dalam analisis fungsional sehingga bisa menjadikan sebuah pedoman yang mengintegrasikan sebuah teori dan riset empiris. Merton menjelaskan pusat dalam analisis ini terdapat pada kelompok, organisasi, masyarakat dan kultur. Serta objek dalam teori ini adalah peran sosial, pola institusional, proses sosial, pola kultur, pola emosi secara kultur, norma sosial, kelompok organisasi, struktur sosial dan sebagai pelengkap adalah pengendali sosial. Tetapi dalam pandangan lain teori ini lebih mencendrungkan kerja seorang laki-laki dari pada wanita walaupun tidak seluruhnya. ${ }^{37}$

\section{Implementasi Potret diri} wanita muslimah dalam Islam

Pada poin ini adalah sebuah ringkasan dari tiga poin diatas setelah melakukan tiga poin diatas, maka dapat diambil sebuah resume pada wanita muslimah yang terjadi pada wanita yang ada

\footnotetext{
${ }^{37}$ Ritzer, 133.
} 
Vol. 13, No. 2, Oktober 2020

p-ISSN:2086 -0749

e-ISSN:2654-4784

di desa Kuala Mandor B. Potret diri yang terjadi pada ibu-ibu yang ada dalam penelitian ini menggambarkan bahwa mereka adalah salah satu wanita yang sangat tangguh demi membiayai keluarga dan anak-anaknya. Hal inilah yang memberikan hikmah kepada para kaum patriarki bahwa masih ada wanita kuat yang masih bekerja ditengah malam yang jauh dari keremaian dan hanya ada kesunyian kecuali suara jangkrik.

Sebagai seorang yang beragama Islam dan muslim tentunya harus benar-benar menjaga dan melindungi dirinya.

Dalam Islam telah dijelaskan seorang muslim harus memelihara serta menjaga kehormatan dirinya. Manusia saat ini tengah hidup di zaman yang mana telah bebas dan terdapat arus globalisasi yang tentunya cenderung dapat merusak keimanan dari seorang muslimah. Terdapat banyak aspek yang diperhatikan di sini, yang salah satunya pergaulan seorang muslimah diperhatikan dengan betul agar tidak terjerumus kepada jalan yang salah. Pada umumnya wanita mudah sekali terseret dalam arus. Mulai dari cara berpakaian, cara berdandan serta bertingkah laku hendaknya harus sesuai dengan syariat yang ada.

Islam memandang pakaian atau busana yang dikenakan oleh wanita tidak hanya yang sekedar menutupi tubuh dari cuaca, untuk membuat diri lebih cantik serta dapat dengan percaya diri dan menarik pandangan dari lawan jenis saja, melainkan berpakaian muslimah di sini sebagai bentuk dari kepatuhan terhadap syariat serta mengimplementasikan seorang hamba terhadap Tuhannya. Tuhan telah memberikan aturan dan batasan- 


\section{Muhammad Munir, Dwi Putri Robiatul Adawiyah}

batasan tertentu tentang cara muslimah berpakaian. Seperti batasan mengenai aurat yang boleh dinampakkan oleh wanita. Aurat dari wanita di sini yaitu seluruh tubuh dari ujung rambut sampai pada ujung kakinya, terkecuali wajah dan telapak tangannya.

Batasan yang telah ada ini merupakan aturan yang telah menjadi ketentuan dari Tuhan. Sesuai dengan firmannya di surat An-Nur ayat 31, selain surat Annur terdapat pula hadist-hadist Nabi Muhammad Saw. Yang mengatakan demikian. Tentunya terlihat Islam ingin sekali untuk memuliakan dan menjaga wanita sampai pada tahap cara berpakaian muslimah. Islam disini beranggapan bahwa pakaian yang tertutup lebih aman daripada yang terbuka. Di sini juga Islam memahami sesuatu yang dibuka terkesan tak bernilai dan murahan. Islam si sini agama yang mengatur segala hal dengan indah dan penuh perhatian. ${ }^{38}$

\section{Simpulan}

Terdapat beberapa temuan dan pembahasan dalam potret diri wanita muslimah antara lain:

Pertama, peran wanita muslimah. Kedatangan Islam menorehkan sejarah yang dibuktikan dalam gerakan femenisme serta nabi sendiri telah mempelopori emansipasi para wanita yang di mulai dari kelurga dan istri-istri dan putrinya, setelah itu juga dilanjutkan oleh para sahabat-sahabat nabi. Peran wanita muslimah ini mencakup pada dua hal yaitu wanita dalam lingkup islam dan Kesamaan Derajat Patriarki dan Femenisme di Hadapan Allah.

Kedua, keberanian wanita muslimah. Dari hal tersebut telah menjabarkan beberapa dari sejarah tentang wanita-wanita yang telah

38 M. Muhsin, Menjadi Muslim Profesional Sesuai Al-Qur'an. (Jakarta: Media Komputindo., 2014). 
Vol. 13, No. 2, Oktober 2020

p-ISSN:2086 -0749

e-ISSN:2654-4784

tampil berani yang telah mencapai derajat yang tinggi dalam Islam. Hal tersebut telah membuktikan tidak sedikitpun Islam membedakan seseorang berdasarkan jenis kelaminnya. Jika ditarik dengan kasus yang telah dilakukan di kecamatan Kaula Mandor B Kabupaten Kuburaya telah sesuai dengan konsep serta contoh sejarah yang ada di Islam, wanita dengan keberaniannya untuk menegakkan segala sesuatu yang benar. Selanjutnya akan dilihat mengenai gambaran pola asuh anak dari wanita muslimah.

Ketiga, pola asuh anak wanita muslimah. Islam menjadi semua solusi atas permasalahan yang terjadi, seperti salah satunya dalam hal mengasuh anak. Saat ini generasi muda bangsa Indonesia sedang mengalami krisis akhlak, yang mana kondisi ini jauh berbeda dengan keadaan dulu, untuk itu diperlukan suatu arahan kepada anak yang sesuai ajaran Islam agar anak memiliki akhlak yang mulia. Terdapat beberapa tahap perkembangan anak, salah satunya masa yang paling penting bagi seorang anak yaitu masa keemasan (golden age) masa ini merupakan kunci dari pembentukan karakter anak, keberhasilan dalam pengasuhan di masa golden age dapat menjadi penentu pada masa remaja dan dewasanya serta menjadikannya seseorang yang dapat berguna bagi nusa dan bangsanya.

Keempat, Analisis Teori Fungsional Struktural. Dalam poin ini peneliti mengkaitkan tiga point diatas dengan dengan teori fungsional struktural, yang kemudian dianalisis menggunakan teori ini. Fungsi dasar dalam teori ini adalah pengelompokan masyarakat berdasarkan fungsinya. 


\section{Muhammad Munir, Dwi Putri Robiatul Adawiyah}

Teori ini dikembangkan oleh

Kingsely Davis dan Wilber Moore yang menjelaskan bahwa pengelompokan sosial masyarakat itu sebagai kejadian yang umum akan tetapi sangat penting.

Kelima, implementasi potret diri wanita muslimah dalam Islam. Sebagai seorang yang beragama Islam dan muslim tentunya harus benar-benar menjaga dan melindungi dirinya. Dalam Islam telah dijelaskan seorang muslim harus memelihara serta menjaga kehormatan dirinya. Selain itu peran muslimah dalam politik sudah sangat sering terjadi. Muslimah terlibat di kegiatan politik tidak hanya untuk kegiatan yang bersifat duniawi saja. Menjadikannya sebagai suatu hal untuk beribadah kepada Allah karena partisipasi politk muslimah ini dengan penuh tanggungjawab dan kesadaran penuh kepada Allah Swt.

\section{Daftar Pustaka}

Abdul Latip Talib (2010) Perang Uhud: catatan duka tentera Islam. Batu Caves, Selangor: PTS Litera Utama.

Anita (2016) Citra Wanita Muslimah Dalam Iklan Di Televisi (Analisis Semiotika terbadap Iklan Sampo Rejoice dan Sampo Sunsilk). Skripsi. Fakultas Dakwah Dan Komunikasi Universitas Islam Negeri Walisongo.

George, R. (2014) Teori Sosiologi Modern. Jakarta: Prenadamedia Grup.

Hamid M Djamil, A. (2016) Seperti Inilah Islam Memuliakan Wanita. Jakarta: PT Elex Media Komputindo.

Ikhsan, S. (2019) Jurus Jitu Mendidik Anak Dalam Kandungan Secara Islami. Jakarta: PT Elex Media Komputindo.

Ismail, N. (2003) Perempuan dalam Pasungan bias Laki-laki dalam penafsiran. Cet. 1. Bantul, Yogyakarta: LKiS Yogyakarta.

Jamhari (ed.) (2003) Citra perempuan Islam: pandangan ormas keagamaan. Jakarta: Gramedia Pustaka Utama bekerjasama dengan PPIMUIN dan the Ford Foundation.

Kusuma, A. (2018) 'Potret Gender Harmoni Pada Keluarga Urban', JURNAL ILMU KOMUNIKASI, 
An-Nisa' : Jurnal Kajian Perempuan \& Keislaman

Vol. 13, No. 2, Oktober 2020

p-ISSN:2086 -0749

e-ISSN:2654-4784

1(1).

doi:

10.33005/jkom.v1i1.9.

Mardinsyah, M. (ed.) (1995)

Hermeneutika Feminisme

Reformasi Gender dalam Islam dalam Budby Munawar

Rahman, Islam dan Feminisme:

dari Sentralitasme kepada

Kesetaraan, dalam Membincang

Feminisme Diskursus Gender

Perspektif Islam dalam Mansur

Faqib (ed) Membincang

Feminisme Diskursus Gender

Perspektif Islam. Surabaya:

Risalah Gusti.

Muhsin, M. (2014) Menjadi Muslim

Profesional sesuai Al-Qur'an.

Jakarta: Media Komputindo.

Murniati, N. (ed.) (2004) Getar Gender. Yogyakarta: IKAPI.

Musdah, S. (ed.) (2011) Membangun Surga di Bumi kiat-kiat membina keluarga ideal dalam Islam.

Novianti, E. (2019) Teori Komunikasi Umum dan Aplikasinya. Yogyakarta: Andi Offset.

Nuryanti, R. and Akob, B. (2019) Perempuan Dalam Historiografi Indonesia (Eksistensi Dan Dominasi). Sleman: CV Budi Utama.

Qardhawi, Y. (2010) Fiqih jihad. Bandung: Penerbit Mizan.
Quțb, S. (1992) Tafsir Fi Zhilalil Qur'an Jilid 5. Beirut: Darusy-Syuruq.

Rokhmansyah, A. (2016) Pengantar Gender Dan Feminism. Yogyakarta: Garudhawarca.

Rosyidah, R. (2019) Potret Wanita Sholehah Dalam Novel (Analisis Wacana Sara Mills Tentang Sosok Wanita Sholehah dalam Novel). Skripsi. Universitas Islam Negri Sunan Gunung Djati Bandung.

Said, N. (2005) Perempuan dalam bimpitan teologi dan HAM di Indonesia. Cet. 1. Yogyakarta: Pilar Media.

Salem Bahammam, A. (2007) Keluarga dan Akblak dalam Islam. Modern Guide.

Samad, M. (2001) Pemberdayaan perempuan muslimab: status, fungsi dan peran wanita Islam dalam era globalisasi. Riau: Yayasan Pusaka Riau.

Sri Suriati Amal, A. (2006) Role Juggling: Perempuan Sebagai Muslimah, Ibu, dan Istri. Jakarta: PT. Gramedia Pustaka.

Syarbini, A. (2014) Model Pendidikan Karakter Dalam Keluarga. Jakarta: PT Elex Media Komputindo. 